\section{Analysis of Green Building Certification Systems Used in Residential Buildings in Turkey, Context of the Resource Conservation}

Dostcan Deligöz ${ }^{1}$, ORCID: 0000-0001-8557-6049

Sueda Kabak², ORCID: 0000-0003-2183-2757

Arda İlayda Aktan³, ORCID: 0000-0003-4082-0348

\section{Keywords}

Breeam; Leed v4.1; Çedbik B.E.S.T; Green Building Certification Systems

\section{Abstract}

Green building certification systems are widely preferred all over the World.. These certification systems, which aim to minimize the use of energy and resources, aim to leave a healthier and livable environment for future generations. BREEAM, Leed and Cedbik were examined in the scope of this study. Within the scope of this study, the comparison of the current versions of the systems used in residential buildings in Turkey as of the end of 2019. In terms of the main sources that constitute input in buildings (energy, water, materials) and it is intended to serve as a guide for construction industry. In order to examine the 3 certificate programs in the study; their history, certification processes, assessment methods and contents, performance criterias and scoring systems were evaluated with these 3 subtitles. In this case, 3 certification systems compared in reference to their guides and literature review findings. There is no subjective conclusion in this study, like which certificate is better or worse. It has been observed that all 3 certification systems address the construction process with a cradle-to-cradle understanding from a sustainability perspective and have similar features, but generally have different percentages in score credits and some subtitles.

\section{Article Information}

Received: 28.05 .2020

Accepted: 28.07.2020

Available Online: 29.07.2020

Article Classification: Research Article

1. Cankaya University, Student in Master Of Architecture, dostcan.d@gmail.com

2. Cankaya University, Student in Master Of Architecture, sueda.kabak1997@gmail.com

3. Cankaya University, Phd Student in Architecture, ilaydasaglam@hotmail.com 


\section{Türkiye'de Konut Yapılarında Kullanılmakta Olan Sertifika Sistemlerinin Kaynakların Korunumu Bağlamında İncelenmesi}

Dostcan Deligöz ${ }^{1}$, ORCID: 0000-0001-8557-6049

Sueda Kabak², ORCID: 0000-0003-2183-2757

Arda İlayda Aktan³, ORCID: 0000-0003-4082-0348

\section{Anahtar Sözcükler}

Breeam; Leed v4.1; Çedbik B.E.S.T; Yeşil Bina Sertifika Sistemleri
$\ddot{\mathrm{O} z}$

Yeşil bina sertifika sistemleri dünyada olduğu gibi, inşaat sektörünün önemli olduğu ülkemizde de tercih edilmektedir. Enerji kullanımı ve kaynak kullanımının minimize edilmesini amaçlayan bu sertifika sistemleri gelecek nesillere daha sağlıklı ve yaşanabilir bir çevre bırakmayı kendilerine amaç edinmişlerdir. Bunlardan başlıcaları olan BREEAM, Leed), Çedbik) çalışma kapsamında incelenmiştir. Çalışma kapsamında ülkemizde konut yapılarında kullanılmış olan sertifika sistemlerinden 2019 sonu itibariyle güncel sürümleri olan Breeam (Int. 2016), Leed (v4.1), Çedbik (B.E.S.T)'in binalarda girdi oluşturan temel kaynaklar özelinde (Enerji, su, malzeme) kıyaslanması ve inşaat sektöründeki müşteriler için bir kılavuz niteliği taşıması amaçlanmaktadır. Çalışmada incelenen 3 sertifika programının bütünsel bir perspektifte incelenebilmesi amacıyla tarihçeleri, sertifikalandırma süreçleri, değerlendirme yöntemleri ve içerikleri, performans kriterleri, enerji performansı sınıflandırma ölçütleri ve puanlama sistemlerinin incelenmesinin ardından 3 temel kriteri ele alış şekilleri değerlendirilmiştir. Sertifika sistemlerinin sitelerinde yer alan kılavuzlar yapılan literatür araştırmasıyla desteklenerek sertifika sistemlerinin hangi faktörleri nasıl ele aldığı kıyaslamalı olarak ele alınmıştır. Çalışmada hangi sertifikanın daha iyi ya da kötü olduğu gibi spekülatif veya sübjektif bir sonuca varılmamaktadır. Her 3 sertifika sisteminin de sürdürülebilirlik perspektifinden beşikten beşiğe anlayışıyla yapı inşa sürecini ele aldığı ve benzer özelliklere sahip olduğu ancak genellikle puan yüzdeleri ve bazı alt başlıklarda birbirinden ayrilan yönleri olduğu görülmüştür.

\section{Makale Bilgileri}

Alındi: 28.05.2020

Kabul edildi: 28.07.2020

Erişilebilir: 29.07 .2020

Makale Kategorisi: Özgün Araştırma Makalesi

1. Çankaya Üniversitesi, Mimarlık Yüksek Lisans Öğrencisi, dostcan.d@gmail.com

2. Çankaya Üniversitesi, Mimarlık Yüksek Lisans Öğrencisi, sueda.kabak1997@gmail.com

3. Çankaya Üniversitesi, Mimarlık Doktora Öğrencisi, ilaydasaglam@hotmail.com 


\section{GİRİ̧ (INTRODUCTION)}

Sanayi devrimi sonrasında ivme kazanan tüketim anlayışı ve beraberinde yaşanan teknolojik gelişmeler hem doğal kaynakların kontrolsüzce tüketilmesini hem de fosil yakıtların kullanımındaki artışı beraberinde getirmiştir. Günümüzde fosil yakıtların binalarda 1sıtma, soğutma gibi birçok alanda kullanılmaya devam edilmesi sebebiyle çevre sorunlarının artması ve doğal kaynakların sınırlı olduklarının anlaşılması üzerine; sürdürülebilirlik ve yeşil bina kavramları gündeme gelmiştir. Bu durumun bir sonucu olarak; çevreye ve doğal kaynaklara zarar vermeden olabildiğince az enerji tüketecek şekilde tasarlanan pasif sistemlerle, önce kendi enerji ihtiyacını karşılayabilen ardından da sarfettiği enerjiden fazlasını üreterek doğaya katkı sağlayan sistemler oluşturulma hedefleri ortaya koyulmuştur. Ancak bu yaklaşımdaki temel eksiklik; yapıların kullanım sürecindeki enerji tüketimlerinin kontrol altına alınmış olmasına karşın, bu yapıların ve yapılarda kullanılan malzemelerin üretim aşamalarında tüketilen enerji miktarının ve ortaya çıkan atıkların sorun teşkil etmeye devam etmesidir.

Bahsi geçen durumlara çözüm bulabilmek adına; yapılarda denetleme ve kontrol sağlamak amacıyla, sertifika sistemleri ortaya çıkmıştır. Hem ulusal hem de uluslararası geçerliliğe sahip olan bu sistemler büyük bir hızla yaygınlaşmış ve farklı yap1 türlerini farklı kriterlere göre değerlendirerek doğaya verilen zararı minimumda tutmayı amaçlayan sistemler olarak önem kazanmışlardır. Bu sistemler yapıları denetleyerek belirli kriterlerler üzerinden sertifikalar veriyor olmaları sebebi ile, yeşil bina sertifikalandırma sistemleri olarak adlandırılmaktadır. Bu çalışmada; Türkiye'de yaygın olarak kullanıldığı tespit edilen, uluslararası yeşil bina sertifika sistemleri olan BREEAM ve LEED ile Türkiye'deki konutları değerlendirmesi için oluşturulmuş olan ulusal sertifika sistemi ÇEDBİK’in, 2019 sonu itibari ile, son sürümlerinin üzerinden incelenme yapılmıştır.

Türkiye'de ve dünyada yap1 stoğunun önemli bir çoğunluğunu oluşturuyor olması sebebi ile, konutlarda kullanılan yeşil bina sertifika sistemleri karşılaştırmalı olarak incelenmektedir. Sistemlerin incelenmesi sırasında, yapılarda sürdürülebilirlik bağlamında, ekolojik sürdürülebilirliğin temel başlıklarından olan kaynakların korunması temel kriter olarak benimsenmiştir. Sürdürülebilir mimarlık ilkeleri kaynakların korunması; enerji, su ve malzemenin korunması olarak açıklanmaktadır (Çelebi, vd., 2008). Bu yaklaşımdan hareketle, ele alınan yeşil bina sertifika sistemlerinde enerji, su ve malzeme kriterleri üzerinden bir değerlendirme yapılmış, sistemlerin bu kriterlere ne şekilde ve hangi ağırllkta yer verdikleri incelenmiştir. 
Çalışma içerisinde, öncelikle sürdürülebilirlik kavramı detaylı olarak ele alınmış, ardından Türkiye'de konut yapıları için kullanılan yeşil bina sertifika sistemleri incelenmiştir. Yapılan incelemelerde, sertifika sistemlerinin yayınladıkları klavuzlar temel kaynak olarak kullanılmaktadır. Söz konusu kılavuzlarda belirltilen kriterler ve puanlama ölçütleri incelenerek, kıyaslamalı bir analiz çalışması yürütülmüştür. Bu araştırmada amaç hangi sistemin daha iyi veya daha kötü olduğu üzerine bir kıyaslama yapmak değildir. Mümkün olduğunca objektif bir bakış açısıyla sistemlerin konuyu ele alış yönlerinin değerlendirilmesi ve dikkate alınan konular üzerindeki farklı bakış açılarınının kıyaslanması amaçlanmaktadır.

\section{LİTERATÜR ÖZETİ (LITERATURE REVIEW)}

\subsection{Sürdürülebilirlik}

Sürdürülebilirlik kavramı, 20. yüzyıldan itibaren, hem Türkiye'de hem de dünya genelinde yürütülen çevre tartışmalarının en önemli başlıklarından birisi olmuştur. Söz konusu tartışmaları ortaya çıartan sebepler; sanayi devrimi ile birlikte hızla artan çevre kirliliği, küresel ssınma, ekolojik dengenin bozulması, hızlı nüfus artış sonucu çarpık kentleşmeler olarak sıralanabilir. Hızla artan dünya nüfusunun da sonucu olarak doğal kaynakların hızla tükeniyor olması ise, çevre hakkındaki temel endişeyi oluşturmaktadır.

Dünya genelinde kalkınmanın, dönemsel ihtiyaçlar doğrultusunda çeşitli değişimler gösterdiği görülmektedir. Ancak gerçekleşen bu değişimlerin, yakın bir geçmişe kadar, kalkınmanın yalnızca sosyokültürel ve ekonomik yönleri ile ilişkili olmuştur. Sanayi devriminin de bir sonucu olarak, kaynakların hızla tükenmesi, çevresel sorunların baş göstermeye başlaması gibi durumlar ise; o güne kadar ele alınan kalkınma planlarının eksikliğini ortaya koymuştur.

Söz konusu eksikliğe bir çözüm önerisi olarak ortaya çıkan sürdürülebilirlik kavramı ise; ilk olarak 1987 Yılında, Dünya Çevre ve Kalkınma Komisyonu (WCED-World Commission on Environment and Development) tarafından yayınlanan Ortak Geleceğimiz (Our Common Future) Raporunda tanımlanmaktadır. Bu raporda sürdürülebilir kalkınma; "Gelecek nesillerin kendi ihtiyaçlarını karşılama yeteneklerinden ödün vermeden mevcut ihtiyaçları karşılayan gelişme" olarak açıklanmaktadır. Bu yaklaşımın yanısıra çevre faktörünün de kalkınmada göz ardı edilmemesi gerektiği belirtilmiştir. Söz konusu Rapor'da çevre; sosyokültürel ve ekonomik faktörlerle birlikte kalkınmanın bir diğer ön koşulu sayılmış ve "bugünün ihtiyaçlarını, gelecek kuşakların kendi ihtiyaçlarını karşılama olanaklarına zarar vermeden karşılamak” düşüncesine vurgu yapılmıştır (WCED, 1983).

Söz konusu yaklaşımın ardından sürdürülebilirlik 3 ana başlıkta incelenmeye başlanmıştır:

- Ekonomik Sürdürülebilirlik

- Çevresel Sürdürülebilirlik

- Sosyokültürel Sürüdürülebilirlik 
Sürdürülebilirlik konusunda yaşanan gelişmelerin sonucunda, gelecek nesillere daha temiz bir dünya bırakmak adına "Dünya Bize Atalarımızdan Miras Değil Çocuklarımızdan Emanettir" düşüncesinden yola çıkarak Birleşmiş Milletler tarafından yerel ve uluslararası ölçekte çeşitli araştırmalar, konferanslar ve paneller düzenlenmeye başlanmıştır ve halen belirli aralıklarla düzenlenmeye devam edilmektedir (Bkz. Tablo 1).

Tablo 1 - Dünyada çevre konusunda düzenlenen konferans ve etkinlikler (Tufan ve Özel, 2018)

\begin{tabular}{|l|l|l|l|}
\hline Y11 & Tür & Şehir & Başlık \\
\hline $\mathbf{1 9 7 2}$ & İnsan ve Çevre Konferans1 & Stockholm & $\begin{array}{l}\text { Only The } \\
\text { Earth }\end{array}$ \\
\hline $\mathbf{1 9 8 7}$ & $\begin{array}{l}\text { Dünya Çevre Konferansı ve Kalkınma } \\
\text { Konferansı }\end{array}$ & $\begin{array}{l}\text { Our Common } \\
\text { Future }\end{array}$ & $\begin{array}{l}\text { Brutland } \\
\text { Raporu }\end{array}$ \\
\hline $\mathbf{1 9 9 2}$ & $\begin{array}{l}\text { Birleşmiş Milletler Çevre ve Kalkınma } \\
\text { Konferansı }\end{array}$ & Rio De Janeiro & Rio Bildirgesi \\
\hline $\mathbf{1 9 9 3}$ & İnsan Haklar1 Konferansı & Viyana & \\
\hline $\mathbf{1 9 9 4}$ & Dünya Nüfus ve Kalkınma Konferans1 & Kahire & \\
\hline $\mathbf{1 9 9 5}$ & Sosyal Kalkınma Konferans1 & Kopenhag & \\
\hline $\mathbf{1 9 9 6}$ & Habitat II & İstanbul & Japonya \\
\hline $\mathbf{1 9 9 7}$ & Kyoto Protokolü & Johannesburg & Rio 10 \\
\hline $\mathbf{2 0 0 2}$ & Sürdürülebilir Gelişme Dünya Zirvesi & Rio De Janeiro & Rio 20 \\
\hline $\mathbf{2 0 1 2}$ & BM Sürdürülebilir Kalkınma Konferans1 & COP 20 \\
\hline $\mathbf{2 0 1 4}$ & BM İklim Değişikliği Müzakereleri & Peru Lima & COP 21 \\
\hline $\mathbf{2 0 1 5}$ & $\begin{array}{l}\text { COP (Convention on Climate Change) 21 } \\
\text { İklim Konferans1 }\end{array}$ & Paris & \\
\hline
\end{tabular}

\subsubsection{Ekonomik Sürdürülebilirlik}

Ekonomik Sürdürülebilirlik yaklaşımı, kaynak kullanım maliyetlerinin minimize edilerek ekonomik kaynakların uzun vadeli kullanılabilmesi adına, gerekli önlemlerin alınması olarak ifade edilmektedir (Şen vd., 2018).

Ekonomik sürdürülebilirlik hedeflerinin başlıca nedenleri;

- Issletme giderlerini azaltmak,

- Ekonominin iyileştirilmesi,

- Hem iş veriminin ve hem de çalışan memnuniyetinin artırılması,

- Mülk değerlerinin ve buna bağlı kazançların artırılması olarak gösterilebilir (Tufan ve Özel, 2018). 
Bu hedeflerin yanı sıra, çevresel ve sosyokültürel faktörlerin göz önünde bulundurulabilmesi için ihtiyaç duyulan ekonomik kaynaklar düşünüldüğ̈nde, ekonomik sürdürülebilirliğin öneminin daha da artmakta olduğu görülmektedir.

\subsection{2. Çevresel Sürdürülebilirlik}

Çevre kavramı üzerine birçok tanım yapılabileceği gibi, bu çalışma bağlamında çevre kavramı; insan ve diğer canlıların etkileşimde bulunduğu fiziki, biyolojik, sosyal, ekonomik ve kültürel ortam olarak tanımlanmaktadır (Şen vd., 2018).

Dünya genelinde çevre sorunların ortaya çıkması ile birlikte, çevresel konular da gündeme gelmeye başlamıştır. Bu konudaki yaklaşımlar ile ilk olarak çevre sorunlarının azaltılması, uzun vadede ise bu sorunları tamamen önleyebilecek önlemlerin alınması gerektiği sonucuna varılmıştır.

Çevresel sürdürülebilirlik ise bu perspektifte; çevresel kaynakların korunmasını ve dış etkenlere karş1 bağışıklılı̆̆ının artırılarak güçlendirilmesini amaçlamaktadır. Doğal kaynakların ve ekosistemin korunmasına yönelik hedefler bütünü, çevresel sürdürülebilirlik ilkesi kapsamında incelenebilmektedir. Dolayısıyla çevresel sürdürülebilirliğin hedefi biyolojik çeşitliliğin korunması ve devamlılığının sağlanmasıdır (Şen vd., 2018).

Tablo 2'de yakın geçmişte ortaya çıkan çevre sorunları ve çözüm önerilerinden bazıları gösterilmektedir.

Tablo 2 - Çevre sorunları ve bu sorunlar için çözüm önerileri (Şen vd.)

\begin{tabular}{|l|l|}
\hline Çevre Sorunları & Çözüm Önerileri \\
\hline Doğal kaynakların hızla tükenmesi & Kaynak ve enerji kullanımının azaltılması \\
\hline Ozon tabakasının delinmesi & Zehirli ve katı atık tüketiminin azaltılması \\
\hline Yer kürenin ısınması & Doğal yaşamın korunması \\
\hline $\begin{array}{l}\text { Toprak, su, hava kirlilikleri ve bunlar kaynaklı } \\
\text { sağlık sorunları }\end{array}$ & $\begin{array}{l}\text { Çevreye duyarlı ürün ve malzemelerin teşvik } \\
\text { edilmesi }\end{array}$ \\
\hline Yoğun nüfus ve buna bağlı çevre kirlilikleri & Çevre bilincinin geliştirilmesi \\
\hline Plansız ve izinsiz yapılaşma & Asit yağmurlarına engel olunması \\
\hline Verimli toprakların kaybı & Küresel 1sınmanın önüne geçilmesi \\
\hline Doğal yaşamın tahrip edilmesi & \\
\hline
\end{tabular}

\subsubsection{Sosyokültürel Sürdürülebilitlik}

Sosyokültürel sürdürülebilirlik, tek bir başlık altında incelenebildiği gibi, sosyal ve kültürel olmak üzere iki ayrı başlık altında da ele alınabilmektedir. 
Sürdürülebilirliğin sosyal boyutu; insanlığın barınma, beslenme, sağlık gibi temel ihtiyaçlarının nasıl karşılanacağını ele almaktadır. Bu kavramların yanı sıra; sosyal adalet, sınıf farklılıklarının ortadan kaldırılması ve kaynaklara eşit ulaşım gibi konular da bu kapsamda değerlendirilebilmektedir (Şen vd. 2018).

Sürdürülebilirliğin kültürel boyutu ise; toplumsal ve kültürel faktörlere odaklanmaktadır. Kültür varlıklarının gelecek nesillere aktarılması ile geçmiş ve gelecek arasında bir köprü oluşturulacağı ve kültürel sürdürülebilirliğin sağlanması adına bir araç olacağı düşünülmektedir (Aydın ve Okuyucu, 2009).

Sürdürülebiliriliğin tarihsel süreci incelendiğinde sosyokültürel boyutun, çevresel ve ekonomik konuların yanında çoğunlukla göz ardı edildiğini söylemek mümkündür. 1987 yılında Brutland Raporu'nda, sürdürülebilir kalkınma planlarından bahsedilirken çevresel sorunların yanı sıra sosyoekonomik yönlerin çevresel sorunlardaki rolüne de değinilmektedir. Bu yeni bakış açısıyla beraber sosyal ve kültürel faktörlerin de kalkınmadaki rolü önemsenmeye başlanmış ve 3.ana başlık olarak literatüre girmiştir (Şen vd. 2018).

\subsection{Mimaride Sürdürülebilirlik}

Sürdürülebilirlik kavramı mimarlık bağlamında incelendiğinde, Kohler’in yaklaşımı ön plana çıkmaktadır. O’nun yaklaşımına göre, sürdürülebilir yapıların; ekolojik, ekonomik ve sosyokültürel sürdürülebilirlik boyutlar üzerinden ele alınması gerekmektedir. Kohler'in yaklaşımına göre, ekolojik sürdürülebilirlik; kaynakların ve ekosistemin korunması, ekonomik sürdürülebilirlik; kaynakların uzun dönem verimliliği ve düşük kullanım bedelini, sosyal ve kültürel sürdürülebilirlik ise; sağlık ve konforun yanı sıra sosyal ve kültürel değerlerin korunmasını kapsamaktadır (Kohler, 1999). Kohler'in yaklaşımdan hareketle tanımlanan sürdürülebilir mimarlığ1 ilkelerine göre ise, kaynakların korunması; enerjinin korunması, suyun korunması ve malzemenin korunmasını kapsamaktadır. Günümüzde kaynakların tükenmekte olması temel çevre problemlerinin başlıcalarındandır. Bina ölçeğinde değerlendirildiğinde ise; enerji, su ve malzeme binaya girdi oluşturan temel kaynak türleridir (Bkz. Şekil 1). Bu kaynakların korunması için gerekli önlemlerin alınması sürdürülebilir mimarlığın başlıca ilkelerinden birisidir (Çelebi, vd., 2008).

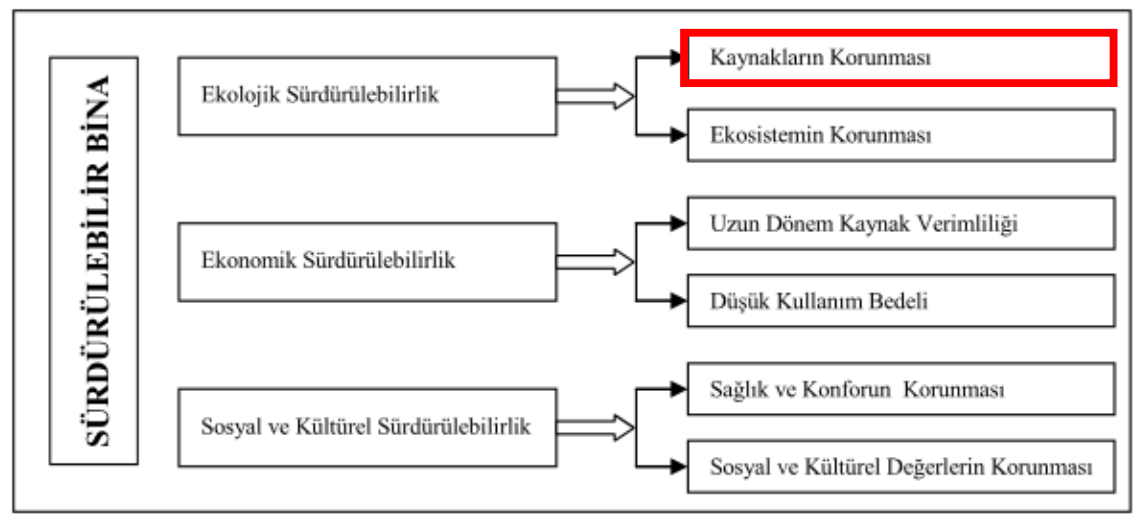

Şekil 1 - Sürdürülebilir Binanın 3 boyutu (Çelebi, vd., 2008) 
Sürdürülebilir tasarıma dair bir başka yaklaşım ise akıllı bina uygulamalarıdır. Bu yaklaşıma göre binaların gelecekteki teknik ve teknolojik yeniliklere sağladıkları adaptasyon sürdürülebilirliktir. J.J.Kim’in yaptığı çalışmada sürdürülebilir mimarlık ilkelerini "Kaynak Ekonomisi”, "Yaşam Döngüsü Tasarımı" ve "İnsani Tasarım” olmak üzere 3 grupta incelemektedir. Çelebi vd. (2008) bu 3 gruptan yola çıkarak sürdürülebilir mimarlığ1; "Kaynakların Korunması", Yaşam Döngüsü Değerlendirme” ve "Yaşanabilir Çevre Tasarımı" ilkeleri üzerine oturtmuşturlar (Bkz. Şekil 2).

Bu yaklaşıma göre;

- Kaynakların korunması ilkesi; doğal kaynak kullanımını minimize etmeyi, geri dönüştürülebilir olmasını, tekrar kullanılabilmesini kapsamaktadır.

- Yaşam döngüsü değerlendirme ilkesi; yapı elde etme sürecinden itibaren yapının yıkımına kadarki tüm sürecinin çevresel etkilerini göz önünde bulundurmaktadır.

- Yaşanabilir çevrelerin tasarımı ilkesi; doğal ve beşeri çevre arasındaki ilişkiyi ele almakta ve birbiri üzerindeki etkilerini göz önünde bulundurmaktadır (Çelebi vd., 2008).

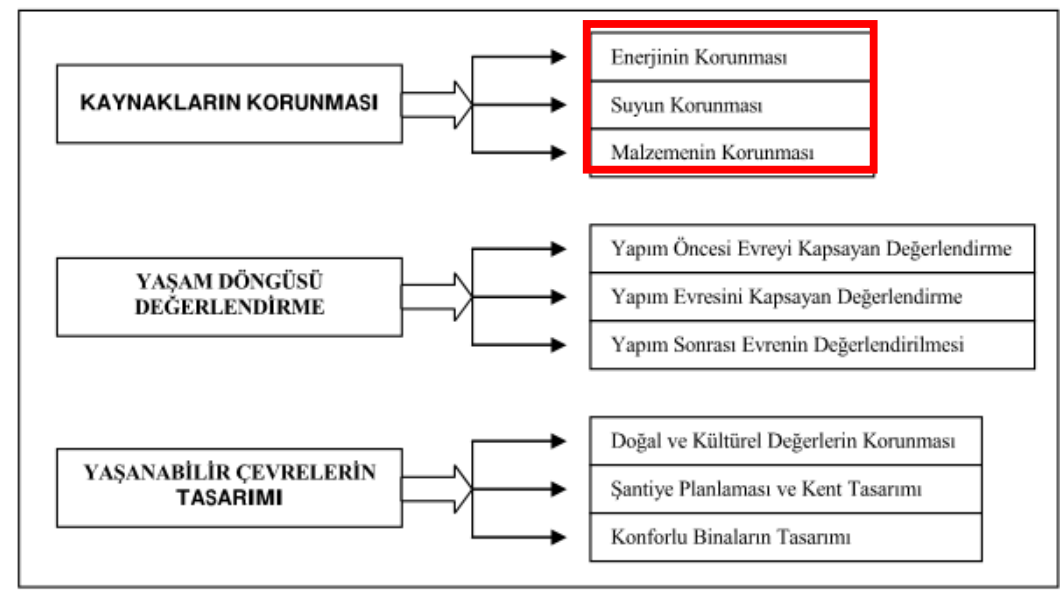

Şekil 2 - Sürdürülebilir Mimarlık İlkeleri (Çelebi, vd., 2008)

Bu bağlamda sürdürülebilir mimarlık, yeşil binalar inşa edilmesi olarak da ele alınabilmektedir. Yeşil Binalar, Birleşik Devletler Yeşil Bina Konseyi (USGBC) tarafından; "çevresel, sosyal ve ekonomik faydalar arasında sağlıklı ve dinamik bir denge kurulmasını hedefleyen, çevre ve kullanıcı üzerinde ortaya çıkabilecek her türlü olumsuz etkiyi belirgin oranda azaltan binalar" olarak tanımlanmaktadır (USGBC, 2019). Çevre Dostu Yeşil Binalar Derneği (ÇEDBİK) ise yeşil binayı; "yapının arazi seçiminden başlayarak yaşam döngüsü çerçevesinde değerlendirildiği, bütüncül bir anlayışla ve sosyal ve çevresel sorumluluk bilinciyle tasarlandığı, iklim verilerine ve yöreye özgü koşullara uygun, ihtiyacı kadar tüketen, yenilenebilir enerji kaynaklarına yönelmiş, doğal ve atık üretmeyen malzemelerin kullanıldığı, katılımı teşvik eden, ekosistemlere duyarlı ve doğayla uyumlu yapılar” olarak açıklamaktadır (ÇEDBİK, 2019). 
Sürdürülebilirliğin yeşil binalar aracillğı ile gerçekleştirilebilmesi için, konut yapıları büyük önem taşımaktadır. Hem dünyadaki hem de Türkiye'deki mevcut yapı stoğu arasında konutlar önemli bir orana sahiptir. Bu durumda da ekolojik bir yaklaşım geliştirebilmek için konut yapılarının ele alınması gerekliliği kaçınılmazdır. Bunun yanı sıra, kamu yapıları ya da ticari yapıların aksine, konut yapılarında enerji tüketiminin tüm gün kesintisiz olarak devam etmesi, bu yapıların enerji sarfiyatı bakımından önemsenmesini gerektiren bir başka sebeptir. Gerçekleştirilen bu çalışma kapsamında, tüm bu sebeplerden hareketle; sertifika sistemlerinin konut ile ilgili yaklaşımları ve puanlama kriterleri ele alınmıştır.

\section{TÜRKIIYE'DE KONUTLAR İÇİN KULLANILAN YEŞİL BİNA SERTİFİKALANDIRMA SİSTEMLERİ (GREEN BUILDING CERTIFICATION SYSTEMS USED IN RESIDENTIAL BUILDINGS IN TURKEY)}

Türkiye'de konut yapılarının değerlendirilmesi için kullanılan yeşil bina sertifikalandırma sistemleri araştırıldığında; uluslararası sistemler olan BREEAM ve LEED Sertifikalandırma Sistemlerinin ve ulusal bir sistem olan B.E.S.T. Sertifikalandırma Sistemi’nin kullanıldığı görülmektedir. Bu sistemlerin Türkiye'de kullanılabilir olan ve konut yapılarını kapsayan, 2020 Yılı Ocak Ayı itibari ile en güncel versiyonları çalışmanın takip eden bölümlerinde incelenecektir.

\subsection{BREEAM}

1990 yılında BRE (Building Establishment) kurumu tarafindan, İngiltere'de geliştirilen BREEAM (Building Research Establishment Environmental Assessment Method) yeşil bina sertifikasyon sistemi; Dünya üzerinde geliştirilen ilk yeşil bina değerlendirme sistemidir. Günümüzde halen en çok kullanılan sertifikalandırma sistemleri arasında bulunmakta ve uluslararası olarak kullanılmaktadır. Breeam Sertifikasyon Sistemleri'nde, sertifika puanını hesaplamak için; Yönetim, Sağlık ve Konfor, Enerji, Ulaşım, Su, Malzeme, Atıklar, Arazi kullanımı ve Ekoloji, Kirlilik ve İnovasyon olmak üzere 10 ana başlık bulunmaktadır. Ancak bu başlıkların ağırlıkları yayınlanan versiyona, uygulandığ1 ülkeye ve yapı tipine göre farkl1lık göstermektedir (BREEAM, 2019).

BREEAM tarafindan en son olarak 2018 yilinda "Breeam UK New Construction 2018 3.0" versiyonu yayınlanmıştır. Bu versiyon İngiltere'de inşa edilecek olan yeni ve konut dışı yapıların değerlendirilmesi için kullanılmaktadır. Ancak bu versiyon yalnızca İngiltere sınırları içerisindeki yapıları kapsadığı için, bu çalışma Türkiye'de kullanılabilen en güncel versiyon olan, Breeam International New Construction 2016 versiyonu üzerinden gerçekleştirilmektedir.

Breeam International New Construction 2016, yeni yapılmakta olan yapıların değerlendirilmesi için kullanılan bir sistemdir. Bu Sistem içerisinde yapılar; konut yapıları, ticari yapılar, eğitim yapıları, uzun süreli konaklama yapıları, oteller ve kısa süreli konaklama yapıları ve standart dışı yapılar olmak üzere toplam 6 ana kategoriye ayrilmakta ve bu bağlamda değerlendirilmektedir (BRE, 2016).

Bu çalışmanın da konusu olan konut yapıları, BREEAM Değerlendirme sistemi içerisinde, tekil aile konutu ve çok daireli konutlar olmak üzere iki alt kategoriye ayrılmaktadır. Söz konusu 
versiyon için puanlandırma sistemi ele alındığında ise, çoğu yeşil bina sertifikalandırma sisteminde olduğu gibi, kriterlere karşılık gelen doğrudan bir puan aralığ1 olmadığ1 görülmektedir. BREEAM Sistemi içerisinde her bir kategorinin kendisine has bir ağırlık ölçüsü bulunmaktadır ve elde edilen puanlar bu ağırlık ölçüsü ile çarpılarak yeni bir değer elde edilir. Bu değerler, incelenmekte olan yapının işlevsel niteliğine (konut, ticari vs.) göre de farklılık göstermektedir. Geçer not alınabilmesi için gerekli puanı sağlamanın yanı sıra kılavuzda belirtilen ön koşulların da yerine getirilmesi gerekmektedir. Geçer not almak için çeşitli maddeler içerisinde toplam 5 ön koşul bulunurken; sertifika derecesi yükseldikçe, sağlanması gereken ön koşullar da artmaktadır. Sistem içerisinde belirtilen ön koşulların yerine getirilmesi şartı ile alınan puanın yüksekliğine göre sırası ile; Geçer, İyi, Çok İyi, Mükemmel ve Seçkin Sertifikaları'na hak kazanılmaktadır (BREEAM, 2019).

Bu versiyonda kullanılan değerlendirme ölçütleri Tablo 3'de, yüzde bazında listelenmektedir. Puanlama sistemi incelendiğinde ise; en büyük ağırlı̆̆ın Enerji ve Malzeme maddelerine verildiği sonrasında ise, Sağlık ve Konfor maddesinin geldiği görülmektedir.

Tablo 3 - Breeam International New Construction 2016 Versiyonu'nun Değerlendirme Ölçütleri Yüzdelik Dağılımı.

\begin{tabular}{|l|l|}
\hline Breeam Değerlendirme Ölçütleri (110p) & Puan \\
\hline Yönetim & 12 \\
\hline Sağllk ve Konfor & 15 \\
\hline Enerji & 19 \\
\hline Ulaşım & 8 \\
\hline Su & 6 \\
\hline Malzeme & 12,5 \\
\hline Atıklar & 7,5 \\
\hline Arazi Kullanımı ve Ekoloji & 10 \\
\hline Kirlilik & 10 \\
\hline İnovasyon & 10 \\
\hline
\end{tabular}

İncelenmekte olan versiyon üzerinden, BREEAM Sertifikalandırma Sistemi'nin, Şekil 3’te de gösterilen, değerlendirme ölçütlerinin yüzdelik dağılımına göre; çalışmanın konusu olan kriterlerden, Enerji \% 17.6, Su \% 5.4, Malzeme \% 11.4 ağırlıklara sahiptir. Bu kriterlerin toplam değerlendirme içerisindeki oranları ise Şekil 3’te gösterilmektedir. 


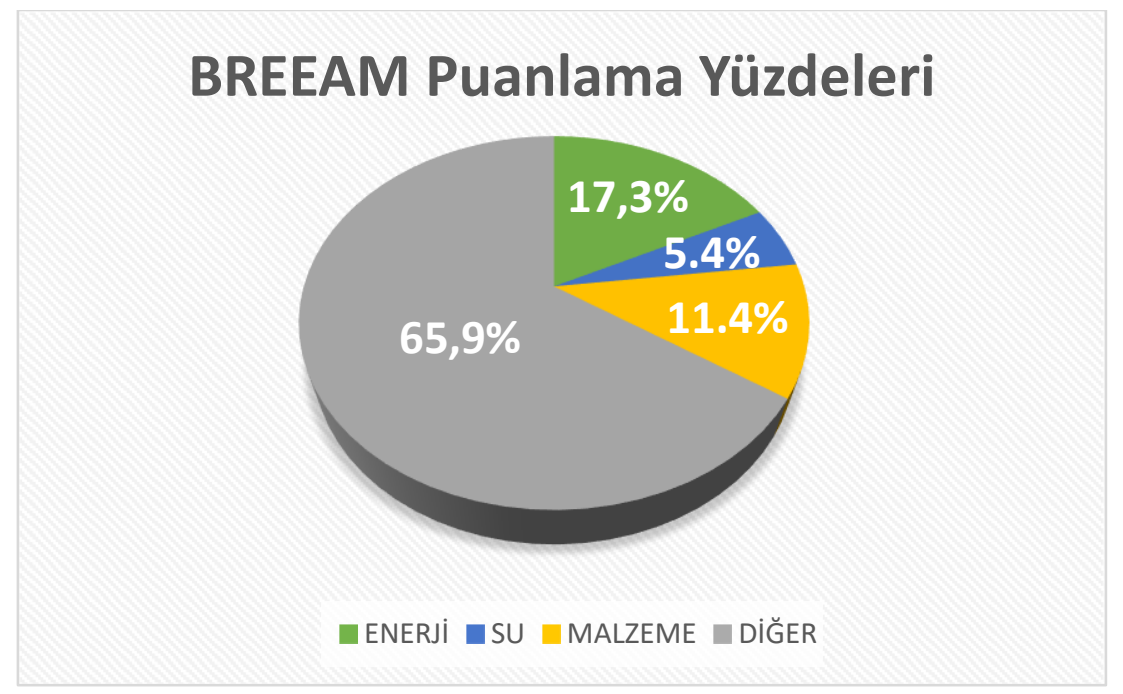

Şekil 3 - Breeam International New Construction 2016 Versiyonunun Değerlendirme Ölçütleri İçerisinde Enerji, Su ve Malzeme Kriterlerinin Ağırlığ11.

Değerlendirme ölçütleri içerisinde Enerji, Malzeme ve Su Kriterleri incelendiğinde ise, toplamda değerlendirmenin \% 37,5’lik kısmını oluşturduğu görülmektedir.

\subsection{LEED}

Diğer bir uluslararası yeşil bina sertifikalandırma sistemi olan LEED (Leadership in Energy and Environmental Design) ise, USGBC (Amerikan Yeşil Binalar Konseyi) tarafindan, 1998 yılında yayınlanmıştır. Leed Sertifika Sistemi'nin şuanda, dünya genelinde en yaygin olarak kullanılan sistem olduğu düşünülmektedir. Yayınlanan en son versiyon olan Leed v4.1'de bina tipleri; Yeni Yapılar ve Büyük Onarımlar, Mevcut Yapılar, İç Mekân, Mahalle Kalkındırma Projeleri ve Konutlar olmak üzere 5 ana kategoriye ayrılmıştır. Yapıların değerlendirilmesi için ise; Sürdürülebilir Araziler, Su verimliliği, Enerji ve Atmosfer, Malzeme ve Kaynaklar, Yerleşim ve Ulaşım, İç Mekân Kalitesi, İnovasyon, Bölgesel Öncelik Kredileri, Bütünleştirici Süreç olmak üzere 9 kategori belirlenmiştir.

Leed Sertifika Sisteminde toplam 110 puana karşlık gelen maddeler bulunmaktadır. Sistem içerisinde bir sertifika almaya hak kazanmak için ise, tüm ön koşulları sağlaması için gerekli olan minimum 40 puanı kazanılması gerekmektedir. 40 - 50 puan aralı̆̆ında Leed Sertifikası kazanılmakta, 50 puandan itibaren ise, elde edilen puana göre sırası ile, gümüş, altın ve platin sertifika alınabilmektedir (LEED, 2019).

LEED Sertifikalandırma Sistemi'nin incelenen versiyonuna göre, değerlendirme ölçütleri, Tablo 4'te puan bazında gösterilmektedir.

\footnotetext{
${ }^{1}$ BRE tarafindan, 2016 Yılında yayınlanan "Breeam International New Construction 2016" Sertifikalandırma Kılavuzundaki bilgilerden yararlanılarak oluşturulmuştur.
} 
Tablo 4 - Leed v4.1 Değerlendirme Ölçütleri Puan Dağılımı².

\begin{tabular}{|l|l|}
\hline LEED Değerlendirme Ölçütleri (110p) & Puan \\
\hline Yerleşim ve Ulaşım & 10 \\
\hline Sürdürülebilir Araziler & 5 \\
\hline Su Verimliliği & 15 \\
\hline Enerji ve Atmosfer & 40 \\
\hline Malzeme ve Kaynaklar & 12 \\
\hline İç Mekân Kalitesi & 16 \\
\hline İnovasyon & 6 \\
\hline Bölgesel Öncelik & 4 \\
\hline Bütünleştirici Süreç & 2 \\
\hline
\end{tabular}

Leed Sertifika Sisteminin değerlendirme ölçütleri incelendiğinde, çalışmanın konusu olan kriterlerden Enerji'nin \% 36.4'lik bir ağırlığ1 olduğu görülmektedir. Enerji başlığ1, kendi başına puanlama sisteminin yaklaşık 3'te 1'ini oluşturmakta ve bu anlamda en önemli kriter olarak yorumlanmaktadır. Diğer kriterler olan; Su \%13.6, Malzeme ise \% 10.9 ağırlı̆ga sahiptir. Bu kriterlerin toplam değerlendirme içerisindeki oranları, Şekil 4’te gösterilmektedir.

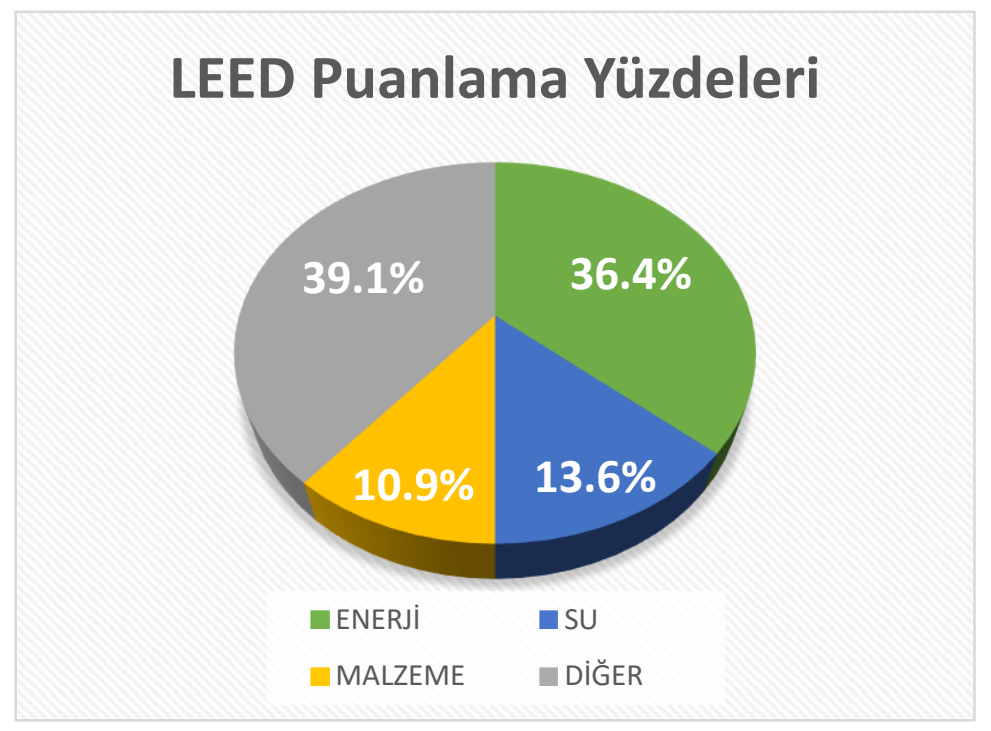

Şekil 4 - LEED V 4.1 Değerlendirme Ölçütleri İçerisinde Enerji, Su ve Malzeme Kriterlerinin Ağırlığ1 ${ }^{3}$.

2 USGBC tarafindan, 2019 Y1lında yayınlanan “Leed v4.1 Residential Single Family Homes” Sertifikalandırma Kılavuzundaki bilgilerden yararlanılarak oluşturulmuştur.

${ }^{3}$ USGBC tarafından, 2019 Yılında yayınlanan "Leed v4.1 Residential Single Family Homes" Sertifikalandırma Kılavuzundaki bilgilerden yararlanılarak oluşturulmuştur. 
Değerlendirme ölçütleri içerisinde Enerji, Malzeme ve Su Kriterleri incelendiğinde ise, toplamda değerlendirmenin \%60,9’luk kısmını oluşturduğu görülmektedir. Bu anlamda ele alınmakta olan bu üç kriterin toplam değerlendirme içerisinde en önemli ve bir anlamda vazgeçilemez kriterler olduğunu söylemek mümkündür.

\section{3. ÇEDBİK}

2015 Yılında, Çevre Dostu Binalar Derneği (ÇEDBİK) tarafindan konutlar için hazırlanmıs, ulusal bir yeşil bina sertifikalandırma kılavuzu oluşturulmuştur. 2019 yllinda bu Kılavuzun güncellenmesi ile de B.E.S.T. Konut Sertifika Sistemi yayınlanmıştır. B.E.S.T. Konut Sertifika Sistemi, güncel olarak Türkiye'de uygulanmakta olan yerel sertifikalandırma sistemidir ve yeni yapılan konutları kapsamaktadır (ÇEDBİK, 2019).

B.E.S.T. Konut Sertifika Sistemi içerisinde, yeni yapılan konutlar; kapladıkları alanın metrekaresine göre 6 kategori altında sinıflandırılmaktadır. Konutların değerlendirilmesi için ise Bütünleşik Yeşil Proje Yönetimi, Arazi Kullanımı, Su Kullanımı, Enerji Kullanımı, Sağlık ve Konfor, Malzeme ve Kaynak Kullanımı, Konutta Yaşam, İşletme ve Bakım, Yenilikçilik olmak üzere 9 ana değerlendirme ölçütü bulunmaktadır. Bu 9 ana ölçüt toplamda 44 alt madde içermektedir ve her bir madde kendi içerisinde puanlandırılmaktadır. Ancak, bazı kategorilerin değerlendirilebilmesi için, belirtilen ön koşulların sağlanması gerekmektedir. Ön koşul olarak belirtilen maddelerden puan alınmamakta ve bu maddelerin gerçekleştirilmemesi durumunda, ilgili kategori tamamen değerlendirme dışı kalmaktadır. Puanlama Sistemi içerisinde ön koşul olarak belirtilen maddeler sırası ile: Bütünleşik Yeşil Proje Yönetimi için, Entegre Tasarım; Su Kullanımı için, Su Kullanımını Azaltma; Enerji Kullanımı için, Kontrol, İşletmeye Alma ve Kabul, Enerji Verimliliği maddeleridir. Yapılan puansal değerlendirmenin sonucunda, sertifika alabilmek için toplamda 110 puanlık değerlendirme üzerinden en az 45 puana ulaşmak gerekmektedir. Bu puanı geçen yapılar ise; aldıkları puan doğrultusunda; Onaylı, İyi, Çok İyi ve Mükemmel derecelerinden bir tanesine karşılık gelen sertifikayı almaya hak kazanmaktadır (B.E.S.T., 2019).

B.E.S.T. Konut Sertifika Sisteminin Değerlendirme Ölçütlerinin puan bazındaki karşl1ıkları Tablo 5'de gösterilmektedir. Puanlama sistemi incelendiğinde; Enerji kullanımının en yüksek ağırllğa sahip olduğu görülmektedir. Sağlık ve Konfor, Malzeme ve Kaynak Kullanımı ve Konutta Yaşam kriterleri ise; puansal ağırlık bakımından ikinci sırada gelen ölçütlerdir.

Tablo 5 - B.E.S.T. Konut Sertifika Sisteminin Değerlendirme Ölçütleri Puan Dağılımı

\begin{tabular}{|l|l|}
\hline B.E.S.T Değerlendirme Ölçütleri & Puan \\
\hline Bütünleşik Yeşil Proje Yönetimi & 9 \\
\hline Arazi Kullanımı & 13 \\
\hline Su Kullanımı & 12 \\
\hline Enerji Kullanımı & 26 \\
\hline
\end{tabular}

\footnotetext{
${ }^{4}$ ÇEDBİK tarafindan, 2019 Yılında yayınlanan “B.E.S.T. - Konut Sertifika Kılavuzu”ndaki bilgilerden yararlanılarak oluşturulmuştur.
} 


\begin{tabular}{|l|l|}
\hline B.E.S.T Değerlendirme Ölçütleri & Puan \\
\hline Sağlık ve Konfor & 14 \\
\hline Malzeme ve Kaynak Kullanımı & 14 \\
\hline Konutta Yaşam & 14 \\
\hline İsletme ve Bakım & 6 \\
\hline Bütünleştirici Süreç & 2 \\
\hline
\end{tabular}

B.E.S.T. Konut Sertifika Sisteminin Değerlendirme Ölçütleri incelendiğinde, çalışmanın konusu olan kriterlerin; Enerji \%23,6, Su \%10,9 ve Malzeme \%12,7 şeklinde ağırlıklara sahip olduğu görülmektedir. Bu kriterler içerisinden Enerji değerlendirme ölçütleri içerisinde en yüksek puana sahip olduğu gibi, bu üç kriterin toplam ağırllğı neredeyse değerlendirmenin yarısına denk gelmektedir. Söz konusu kriterlerin puanlama yüzdelerinin, değerlendirme içerisindeki ağırlıkları Şekil 5.'te gösterilmektedir.

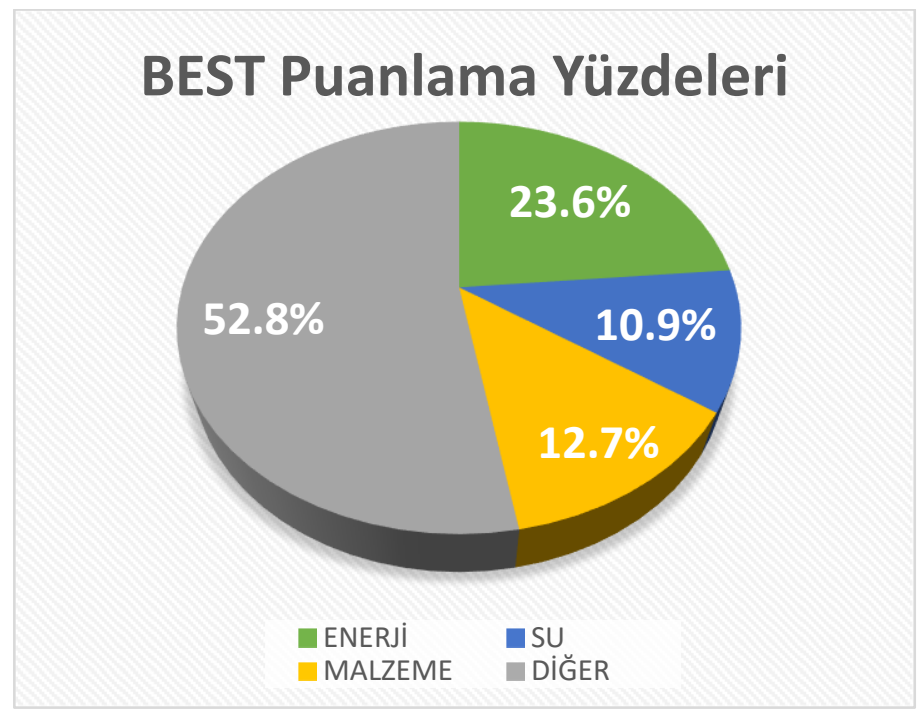

Şekil 5 - BEST Değerlendirme Ölçütleri İçerisinde Enerji, Su ve Malzeme Kriterlerinin Ağırllı̆̆1

\section{TÜRKİYE'DE KONUTLAR İÇİN KULLANILAN YEŞİL BİNA} SERTİFIKALANDIRMA SİSTEMLERİNINN ENERJİ, SU VE MALZEME ÜZERINNDEN İNCELEMESİ (ANALYSIS OF GREEN BUILDING ENERGY CERTIFICATION SYSTEM ON ENERGY, WATER AND MATERIAL IN TURKEY)

BREEAM, LEED ve BEST Sertifikalandırma Sistemlerinin ele alınan versiyonlarında değerlendirme ölçütleri içerisinde enerji, su ve malzeme kriterleri yüzdelik oranları bakımından değerlendirilmiştir (Bkz. Şekil 6).

${ }^{5}$ ÇEDBİK tarafindan, 2019 Yılında yayınlanan “B.E.S.T. - Konut Sertifika Kılavuzu”ndaki bilgilerden yararlanılarak oluşturulmuştur. 


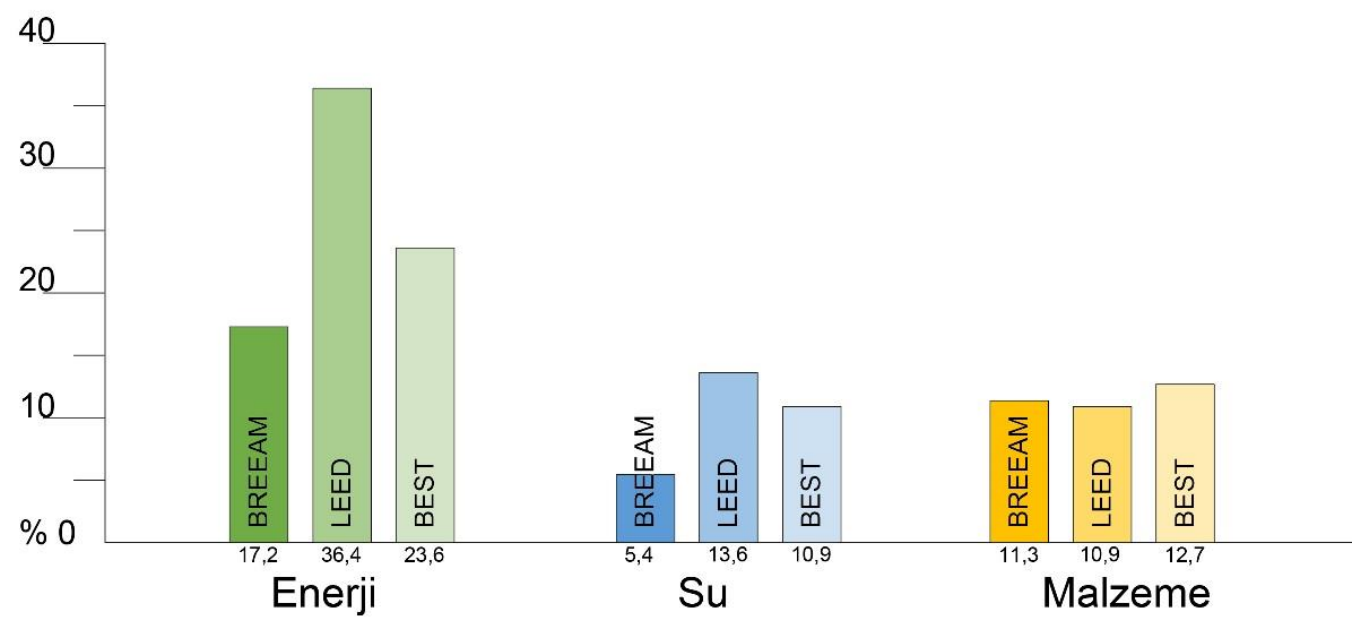

Şekil 6 - Türkiye'de Konutlar için kullanılan güncel BREEAM, LEED ve B.E.S.T. Konut Sertifika Sistemleri'nin değerlendirme ölçütleri içerisinde Enerji, Su ve Malzeme maddelerinin puanlama yüzdeleri ${ }^{6}$.

Yapılan bu değerlendirmeye göre, LEED’in enerjiye verdiği ağırlık oldukça yüksektir. LEED’in enerji maddesi, hem kendi değerlendirme sistemi içerisinde oldukça yüksek bir oranda bulunmakta, hem de diğer sistemler ile \%10-15’lik bir fark göstermektedir. Enerji konusunda BEST ikinci yüksek yüzdeye sahipken, BREEAM en düşük ağırlığa sahiptir.

Su maddesi incelendiğinde, LEED ve B.E.S.T.'in birebir aynı oranda olduğu, BREEAM'in ise en düşük yüzdeye sahip olduğu görülmektedir. Malzeme konusunda ise, BREEAM ile B.E.S.T.'in neredeyse aynı yüzdede olduğu söylemek mümkündür. Malzeme kategorisi, bu üç kategori içerisinde, LEED’in en düşük yüzdeye sahip olduğu tek kategoridir.

Tablo üzerinden gerçekleştirilen bu okumadan yola çıkarak; üç sistemin de en büyük ağırllğ̣ enerjiye vermesinin yanında bu konuya LEED'in sayısal olarak ağırllğı verdiği söylenebilir. Su konusunda BREEAM; hem diğer sistemlerle, hem de kendi içerisindeki diğer kriterlerle kıyaslandığında daha düşük bir ağırlığıa sahiptir. Malzeme konusunda, çok büyük bir farkla olmasa dahi, LEED'in değerlendirme yüzdesinin düşük olması da bu konuda sayısal olarak diğer sertifika sistemlerinin konuyu daha fazla göz önünde bulundurduğunu göstemektedir.

Binaya girdi oluşturan temel kaynakları değerlendiren 3 kriterin toplam ağıllı̆ına bakıldığında ise LEED'de bu üç kriterin yüzdelerinin toplamı \%60.9 ile en yüksek orana sahiptir. BEST \%47.5 oranına sahipken, BREEAM'de üç kriterin toplamı ile \%36.4 ağıllığına ulaşmaktadır. Bu anlamda bu üç kriteri değerlendirmesi içerisinde en az seviyede dikkate alanın BREEAM olduğu düşünülmektedir.

\footnotetext{
${ }^{6}$ Breeam International New Construction 2016, Leed v4.1 Residential Single Family Homes 2018 ve B.E.S.T. Konut Sertifika Kılavuzu 2019'daki bilgilerden yararlanılarak oluşturulmuştur.
} 


\subsection{Enerji}

BREEAM, LEED ve BEST Sertifika Sistemleri'nin ele alınmakta olan versiyonlarında bulunan "Enerji" maddeleri, bu maddenin alt başlıkları bakımından incelenmiş ve sistemler arası kıyaslama sağlanması amacı ile tablolaştırılmıştır (Bkz. Tablo 6).

Söz konusu tablo incelendiğinde, bu üç sistemin örtüşen ve ayrışan yanları görülmektedir. Minimum Enerji Tüketimi üç sistem için de ortaklaşan tek kriter olmuştur. Enerji Ölçümü, Enerji Verimli Ekipman, Enerji Verimli Sistemler, İklimlendirme Sistemleri ve Dış Aydınlatma kriterleri bu sistemlerin iki tanesinde bulunurken bir tanesinde bulunmamaktadır. Düşük Karbonlu Tasarım, Yenilenebilir Enerji Kullanımı, Eğitim, HVAC Değerlendirmesi ve Kontrol ise bu sistemlerden yalnızca bir tanesinde bulunmaktadır.

Ortaklaşan ve ayrışan kriterler incelendiğinde ise, temel kaygının enerji tüketiminin minimize edilmesi olduğu görülmektedir. Bu durumun yanı sıra; kullanılan enerjinin ölçülmesi, enerji verimli ekipman ve sistemlerin kullanılması da önemsenen durumlar arasından sayılmaktadır. Enerjinin ölçülmesi ve enerji verimli ekipman sistemlerinin kullanılması da önemsenen durumlar arasında sayılmaktadır. Enerjini ölçülmesi ve enerji verimli ekipman kullanımlarından da aslında enerji tüketimini minimize etmenin yöntemleri olduğunu söylemek mümkündür.

Tablo 6 - Türkiye'de Konutlar için kullanılan güncel BREEAM, LEED ve B.E.S.T. Konut Sertifika Sistemleri'nin Enerji Değerlendirme Ölçütleri.

\begin{tabular}{|c|c|c|c|}
\hline \multicolumn{4}{|c|}{ Konutlar için Enerji Değerlendirme Kriterleri } \\
\hline & BREEAM & LEED & BEST \\
\hline Ön Koşul & - & $\begin{array}{l}\text { *Minimum enerji } \\
\text { performansı } \\
\text { *Enerji Ölçümü } \\
\text { *Ev sahibi, kiracı veya } \\
\text { bina yöneticisinin } \\
\text { eğitimi }\end{array}$ & $\begin{array}{l}\text { *Kontrol işletmeye } \\
\text { alma ve kabul } \\
\text { *Enerji verimliliği }\end{array}$ \\
\hline \multirow{2}{*}{$\begin{array}{l}\text { Minimum Enerji } \\
\text { Kullanımı }\end{array}$} & \multirow{2}{*}{$\begin{array}{l}\text { Enerji kullanımı ve karbon } \\
\text { emisyonlarının azaltılması }\end{array}$} & $\begin{array}{l}\text { Minimum enerji } \\
\text { performans } 1\end{array}$ & \multirow[t]{2}{*}{ Enerji verimliliği } \\
\hline & & Yıllık enerji kullanımı & \\
\hline $\begin{array}{l}\text { Düşük Karbonlu } \\
\text { Tasarım }\end{array}$ & Düşük karbonlu tasarım & - & - \\
\hline $\begin{array}{l}\text { Yenilenebilir } \\
\text { Enerji Kullanımı }\end{array}$ & - & - & $\begin{array}{l}\text { Yenilenebilir enerji } \\
\text { kullanımı }\end{array}$ \\
\hline Enerji Ölçümü & Enerji İzleme & Enerji ölçümü & - \\
\hline
\end{tabular}

\footnotetext{
${ }^{7}$ Breeam International New Construction 2016, Leed v4.1 Residential Single Family Homes 2018 ve B.E.S.T. Konut Sertifika Kılavuzu 2019'daki bilgilerden yararlanılarak oluşturulmuştur.
} 


\begin{tabular}{|c|c|c|c|}
\hline & BREEAM & LEED & BEST \\
\hline \multirow{2}{*}{$\begin{array}{l}\text { Enerji Verimli } \\
\text { Ekipman }\end{array}$} & \multirow[t]{2}{*}{ Enerji verimli ekipman } & \multirow[t]{2}{*}{-} & $\begin{array}{l}\text { Enerji verimli beyaz } \\
\text { eşya }\end{array}$ \\
\hline & & & Asansörler \\
\hline $\begin{array}{l}\text { Enerji Verimli } \\
\text { Sistemler }\end{array}$ & Yaşam Döngüsü & - & - \\
\hline $\begin{array}{l}\text { İklimlendirme } \\
\text { Sistemleri }\end{array}$ & - & - & - \\
\hline Diş Aydınlatma & - & - & Diş aydınlatma \\
\hline Ĕ̈itim & - & $\begin{array}{l}\text { Ev sahibi, kiracı veya } \\
\text { bina yöneticisinin } \\
\text { eğitimi }\end{array}$ & - \\
\hline $\begin{array}{l}\text { HVAC } \\
\text { Değerlendirmesi }\end{array}$ & - & $\begin{array}{l}\text { HVAC } \\
\text { değerlendirmesi }\end{array}$ & - \\
\hline Kontorl & - & & $\begin{array}{l}\text { Kontrol, işletmeye alma } \\
\text { ve kabul }\end{array}$ \\
\hline \multicolumn{4}{|l|}{ Ön Koşullar } \\
\hline \multicolumn{4}{|c|}{ Bütün Sistemlerde Ortak Bulunan Kriter } \\
\hline \multicolumn{4}{|c|}{ İki Sistemde Ortak Olarak Bulunan Kriter } \\
\hline \multicolumn{4}{|c|}{ Yalnızca Bir Sistemde Bulunan Kriter } \\
\hline
\end{tabular}

\section{2. $\mathrm{Su}$}

BREEAM, LEED ve BEST Sertifika Sistemleri'nin ele alınmakta olan versiyonlarında bulunan Su maddeleri, bu maddenin alt başlıkları bakımından incelenmiş ve sistemler arası kıyaslama sağlanması amacı ile tablolaştırılmıştır (Bkz. Tablo 7).

Tablo 7 - Türkiye'de Konutlar için kullanılan güncel BREEAM, LEED ve B.E.S.T. Konut Sertifika Sistemleri'nin Su Değerlendirme Ölçütleri ${ }^{8}$

\begin{tabular}{|l|l|l|l|}
\hline \multicolumn{4}{|c|}{ Konutlar İçin Su Değerlendirme Kriterleri } \\
\hline & BREEAM & LEED & BEST \\
\hline Ön Koşul & - & $\begin{array}{l}\text { *Su Kullanımı } \\
\text { *Su Ölçümü }\end{array}$ & *Su kullanımını azaltma \\
\hline Su Kullanımı & Su tüketimi & İç mekan su kullanımı & Su kullanımını azaltma \\
\hline
\end{tabular}

\footnotetext{
${ }^{8}$ Breeam International New Construction 2016, Leed v4.1 Residential Single Family Homes 2018 ve B.E.S.T. Konut Sertifika Kılavuzu 2019'daki bilgilerden yararlanılarak oluşturulmuştur.
} 


\begin{tabular}{|l|l|l|l|}
\hline & & $\begin{array}{l}\text { Diş mekan su } \\
\text { kullanımı }\end{array}$ & \\
\hline & BREEAM & LEED & BEST \\
\hline Su Ölçümü & Su izleme & Su ölçümü & - \\
\hline Su Kayıpları & Su kaçağı tespit ve önleme & - & Su kayıplarını önleme \\
\hline $\begin{array}{l}\text { Su Verimli } \\
\text { Ekipman }\end{array}$ & Su verimli ekipman & - & - \\
\hline $\begin{array}{l}\text { Atık Su } \\
\text { Değerlendirme }\end{array}$ & - & - & $\begin{array}{l}\text { Atık su arıtma ve } \\
\text { değerlendirme }\end{array}$ \\
\hline $\begin{array}{l}\text { Yer Altı Su } \\
\text { Seviyesinin } \\
\text { Korunması }\end{array}$ & - & - & Yüzeysel su akışı \\
\hline & $\begin{array}{l}\text { Ön Koşullar } \\
\text { Bütün Sistemlerde Ortak Bulunan Kriter } \\
\text { İki Sistemde Ortak Olarak Bulunan Kriter } \\
\text { Yalnızca Bir Sistemde Bulunan Kriter }\end{array}$ & \\
\hline
\end{tabular}

Söz konusu sistmlerde Su kriterini inceleyen tablo incelendiğinde, bu üç sistemin örtüşen ve ayrışan yanları görülmektedir. Su Kullanımı, üç sistemde de ortak olarak bulunan ve iki sistemin ön koşulu olarak ortaya konan kriter olarak, bu maddenin temel amacını yansıtmaktadır. LEED su kullanımını iç mekan ve dış mekan su kullanımı olarak ikiye ayırmaktadır ancak diğer sistemlerde böyle bir ayrım yoktur.

Sistemlerin ikisinde ortak olarak bulunan kriterler; Su ölçümü ve Su kayıplarıdır. Bu maddeler de su kullanımını azaltmaya yönelik yöntemler önermektedir. Su Verimli Ekipman, Atık Su Değerlendirme ve Yer Altı Su Seviyesinin Korunması ise yalnızca bir sistemde bulunan kriterlerdir.

Su maddesinin alt başlıkları incelendiğinde, sistemler arasında yöntemsel olarak ayrışmalar varmış gibi görünse de, üç sistemin de ulaşılan sonuç bağlamında ortaklaştığını söylemek mümkündür. Bu noktada en çok ayrışan durumun, BEST’de bulunan atık suların dönüşümünün diğer sistemlerde bulunmaması olduğu düşünülmektedir. Bu maddenin yanısıra, yeraltı su seviyesinin korunması ile ilgili kriter de yalnızca BEST'de bulunmaktadır. Su verimli ekipman ise, yalnızca BREEAM sisteminde bulunan bir kriterdir.

\subsection{Malzeme}

BREEAM, LEED ve BEST Sertifika Sistemleri'nin ele alınmakta olan versiyonlarında bulunan Malzeme maddeleri, bu maddenin alt başlıkları bakımından incelenmiş ve sistemler arası kıyaslama sağlanması amacı ile tablolaştırılmıştır (Bkz. Tablo 8). 
Ele alınan Sistemlerde Malzeme maddesi incelendiğinde; Dayanıklılık konusunda üç sistemin de ortaklaştığı görülmektedir. Dayanıklı malzemelerin kullanılması uzun vadede kazanım sağlayacağından, bu sistemler içerisinde önemli olduğu düşünülmektedir. Ancak, bu kriter sistemlerin hiçbirinde en yüksek puana sahip kriter değildir. Çevre Dostu Malzeme, LEED ve BEST sistemlerinde ortaklaşan ve iki sistemde de en yüksek puanı alan kriterdir. Bu madde yerine BREEAM’de yaşam döngüsü kriteri bulunmaktadır. Malzeme Verimliliği ve Yap1 Malzemelerinin Kaynağı iki sistemde ortaklaşan diğer kriterlerdir. Yapı malzemelerinin kaynağı maddesinde geçen, yasal olarak kesilmiş kereste kullanma hem BREEAM, hem de LEED Sistemlerinde ön koşul olarak da yer almaktadır. Bu kriterlerin yanı sıra; Atık Yönetimi, Malzeme Geri Dönüşümü ve Yerel Malzeme Kullanımı da yalnızca bir sertifika içerisinde bulunan kriterlerdir.

Tablo 8 - Türkiye'de Konutlar için kullanılan güncel BREEAM, LEED ve B.E.S.T. Konut Sertifika Sistemleri'nin Malzeme Değerlendirme Ölçütleri ${ }^{9}$

\begin{tabular}{|c|c|c|c|}
\hline \multicolumn{4}{|c|}{ Konutlar için Malzeme Değerlendirme Kriterleri } \\
\hline & BREEAM & LEED & BEST \\
\hline Ön Koşul & $\begin{array}{l}\text { *Yasal olarak kesilmiş } \\
\text { kereste kullanımı }\end{array}$ & $\begin{array}{l}\text { *Sertifikalı tropikal } \\
\text { ahşap } \\
\text { *Dayanıklılık yönetimi }\end{array}$ & - \\
\hline $\begin{array}{l}\text { Yap1 } \\
\text { Malzemelerinin } \\
\text { kaynağı }\end{array}$ & $\begin{array}{l}\text { Yap1 malzemelerinin } \\
\text { kaynağ1 }\end{array}$ & $\begin{array}{l}\text { Sertifikalı tropikal } \\
\text { ahşap }\end{array}$ & - \\
\hline $\begin{array}{l}\text { Malzeme } \\
\text { Verimliliği }\end{array}$ & Malzeme verimliliği & $\begin{array}{l}\text { Malzeme verimli } \\
\text { çerçeveleme }\end{array}$ & - \\
\hline $\begin{array}{l}\text { Çevre Dostu } \\
\text { Malzeme }\end{array}$ & - - & $\begin{array}{l}\text { Çevreye duyarlı } \\
\text { ürünler }\end{array}$ & Çevre dostu malzeme \\
\hline \multirow[b]{2}{*}{ Dayanıklı1ık } & \multirow[b]{2}{*}{$\begin{array}{l}\text { Dayanıklılık ve esneklik } \\
\text { için tasarım }\end{array}$} & Dayanıklılık yönetimi & \multirow[b]{2}{*}{ Dayanıklı malzeme } \\
\hline & & $\begin{array}{l}\text { Dayanıklılık yönetimi } \\
\text { doğrulamas1 }\end{array}$ & \\
\hline Atık Yönetimi & - & \begin{tabular}{|l|}
$\begin{array}{l}\text { İnşaat atıklarının } \\
\text { yönetimi }\end{array}$ \\
\end{tabular} & - \\
\hline $\begin{array}{l}\text { Malzeme Yaşam } \\
\text { Döngüsü }\end{array}$ & Yaşam Döngüsü & - & - \\
\hline \multirow{2}{*}{$\begin{array}{l}\text { Malzeme Geri } \\
\text { Dönüşümü }\end{array}$} & \multirow{2}{*}{-} & \multirow[b]{2}{*}{ |- } & $\begin{array}{l}\text { Malzemenin yeniden } \\
\text { kullanımı }\end{array}$ \\
\hline & & & $\begin{array}{l}\text { Mevcut bina } \\
\text { elemanlarının kullanımı }\end{array}$ \\
\hline $\begin{array}{l}\text { Yerel Malzeme } \\
\text { Kullanımı }\end{array}$ & |- & - & $\begin{array}{l}\text { Yerel malzeme } \\
\text { kullanımı }\end{array}$ \\
\hline
\end{tabular}

\footnotetext{
${ }^{9}$ Breeam International New Construction 2016, Leed v4.1 Residential Single Family Homes 2018 ve B.E.S.T. Konut Sertifika Kılavuzu 2019'daki bilgilerden yararlanılarak oluşturulmuştur.
} 
İki Sistemde Ortak Olarak Bulunan Kriter

Yalnizca Bir Sistemde Bulunan Kriter

\section{DEĞERLENDİRME (DISCUSSION)}

Gerek dünyada gerekse Türkiye'de, diğer sektörler arasında kendine önemli bir yer edinmiş ve ülkelerin kalkınma konularında çoğu zaman söz sahibi olan yapı sektörünün bu etkisi günümüzde de devam etmektedir. Artan yapılaşma hammadde ve doğal kaynak tüketimini de beraberinde getirdiği gibi meydana gelen atıkların (yaklaşık \%50'si) büyük bir kısmindan da sorumludur. Hammadde ihtiyac1 sebebiyle, doğal kaynaklardan elde edilen ilk ürünlerin \%50'si, suyun \%16's1 ve son olarak yine doğal kaynaklı enerjinin \%40’1 bu sektörün tüketim oranlarıdır (Sev, 2009). Bu denli yüksek oranlarda kullanımın söz konusu olduğu, ayrıca gelişim ivmesinin de oldukça yüksek olduğu bir alanda bu seviyelerde bir tüketimin hiçbir iyileştirme süreci yaşamadan devam etmesi, beraberinde birçok çevresel sorunu da getirmektedir (Geçer, vd., 2018). Tüm bu sebeplerden dolayı ortaya çıkan yeşil bina kavramı, ekonomik ve kültürel sürdürülebilirlik alanlarında olduğu gibi çevresel sürdürülebilirlik bağlamında da incelendiğinde büyük oranlarda tüketimi yapılan su, enerji ve malzeme olmak üzere bu üç ana başlı̆̆ın etkin ve sistematik kullanımı açısından önem kazanmaktadır.

Bu çalışmada, Türkiye'de Konutlar için kullanılan güncel BREEAM, LEED ve B.E.S.T. Konut Sertifika Sistemleri enerji, su ve malzeme başlıkları üzerinden incelenmiştir. Yapılan incelemeler sonucunda; üç sistem bu bağlamda birbirleri ile kıyaslanmaktadır.

Yapılan değerlendirmeler sonucunda, üç sistemde de en çok önemsenen kriterin enerji olduğu açıkça görülmektedir. Enerji kriterinin oranının en yüksek olduğu sistem LEED'dir. LEED'in kendi değerlendirme ölçütlerinin üçte birinden fazla bir değeri yalnızca enerji başlı̆̆ altında, kendi sistemi hakkında da bilgi vermektedir. Kaynakların tükenmesinde de bahsi geçtiği üzere, enerji sürdürülebilirlik için en kritik konulardan bir tanesidir. Bu anlamda en ciddi yaklaşımın LEED’e ait olduğu söylenebilir. LEED’in ön koşulları içerisinde Minimum Enerji Performansı ve Enerji Ölçümünün bulunması da bu durumu kanıtlar niteliktedir.

Enerji başlı̆̆1 altında sistemler incelendiğinde, yüzdelik oran açısından, ikinci sırada BEST’in geldiği görülmektedir. BEST'in yenilenebilir enerji kullanımı kriteri barındırması, bu konun dikkat çeken unsurlarındandır. Bu anlamda BEST’in yaklaşımı, Türkiye'nin gelişmeye açık bir profile sahip olması bakımından, gelecek vaat eden bir yapıdadır. Yenilenebilir enerji kaynaklarının teşvik eldilmesinin, Türkiye'nin gelişim sürecinde olumlu etkileri olacağı gibi, enerji tüketiminin kontrol altına alınması bakımından da verimli bir yol olacağı düşünülmektedir.

Enerji bağlamında BREEAM’in dikkat çeken yanlarında bir tanesi, karbon emisyonu ve düşük karbonlu tasarıma yaptığ1 vurgudur. Enerji verimliliği bütün sistemlerde tartsşlan temel nokta olsada, yalnızca BREEAM karbon konusunu kriter başlıklarına kadar taşımıştır. Bu konunun diğer sistemlerde de önemsenen bir unsur olduğu görülse de, en dikkat çeken vurguyu BREEAM'in yaptı̆̆1 görülmektedir. 
Su kriteri için değerlendirme yapıldığında ise, gözlemlenen bir nokta; BREEAM'de su kriteri diğer sistemlere göre oldukça düşük bir seviyede olduğudur. Bu durumun sistemlerin oluşturulduğu bölgeler arasındaki coğrafi farklılık sebebi ile ortaya çıktığı düşünülmektedir. $\mathrm{Bu}$ durum BREEAM'in İngiltere koşullarına göre geliştirilmiş bir sistem olması, iklim koşulları sebebi ile de, su probleminin daha az yaşanmasının bir yansıması şeklinde yorumlanabilir. Aynı şekilde, BEST Sisteminde bulunan yer altı su seviyesinin korunması kriterleri de Türkiye'nin coğrafi koşulları gözetilerek oluşturulmuş bir madde olarak yorumlanabilir.

Su konusunda en az alt başlı̆ga sahip olmasına karşın, yalnızca LEED'in su kullanımını iç mekan ve dış mekan kullanımı olarak ayırması dikkat çeken bir diğer noktadır. LEED iç mekan su kullanımına 11 puan verirken, dış mekan kullanımına 4 puan vermektedir. Bu durum, temel hedefin iç mekandaki su kullanımını azaltmak olduğu şeklinde de yorumlanabilir. LEED'in Su kullanımı ve Su ölçümünü ön koşul olarak koyması da bu durumu ne kadar önemsediğini gösterir niteliktedir.

BEST’te ise, su maddesinin yüzdesel ağılı̆ğı LEED ile aynıdır. BEST’te de su kullanımını azaltma ön koşul olarak belirtilmektedir. BEST’in su ile ilgi durumlar hakkında geniş bir değerlendirmede bulunduğu gözlemlenmektedir.

Malzeme başlığı ele alındığında ise, en önem verilen konulardan birinin yasal yollarla elde edilmiş kerestelerin kullanılması olduğunu söylemek mümkündür. Bu madde hem BREEAM hem de LEED'de ön koşul olarak belirtilmiştir. Bu durum, kereste kullanımının çevresel bir sorun olduğu şeklinde de ifade edilebilir. Üç sistemde de ortaklaşan nokta olan dayanıklılık ise, yapıların uzun vadeli kullanılmasının amaçlandığını ortaya koymaktadır. En yüksek puanlı alt kriter olan çevreye duyarlı malzeme kullanımı ise, doğrudan sürdürülebilirliğin bir gereğidir.

Malzeme konusunda en dikkat çeken ayrım ise, BEST'in ortaya koyduğu Malzemenin Yeniden Kullanımı ve Mevcut Bina Elemanlarından Yararlanılması kriterleri üzerinden oluşmaktadır. Diğer sistemlerde malzemelerin yaşam döngüsüne dair kriterler olmasına karşın, malzemenin yeniden kullanılmasına ilişkin bir madde bulunmamaktadır. Bu durum Türkiye'nin sosyokültürel durumunun sonucunda geliştirilmiş bir öneri olabileceği gibi, Türkiye'deki yapılaşma hızı ile ilgili bir durum da olabilir. Türkiye'de yapılar çok kısa süreler kullanıldıktan sonra yıkılıp tekrar yapılmaktadır. Bu anlamda, malzemelerin yeniden kullanımı ya da mevcut bina elemanlarından yararlanmak, oldukça önemli bir yaklaşım olacaktır. Bu durumun yanı sıra "Yerel Malzeme Kullanımı" da yalnızca BEST'de önerilen bir kriterdir.

\section{SONUÇ (CONCLUSION)}

Yaşanan gelişmeler ve çevresel değişimlerin paralelinde ortaya çıkan yeşil bina kavramının ve bu binaların sertifikalandırılması üzerine geliştirilen sistemlerin her geçen gün önem kazandığı görülmektedir. Bu çalışmada da, Türkiye'de konut yapılarının değerlendirilmesi için kullanıldığ1 bilinen BREEAM, LEED ve BEST Yeşil Bina Sertifikalandırma Sistemleri'nin, 2019 sonu itibari ile, en güncel versiyonlarının; sürdürülebilir mimarlık ilkelerinden kaynakların korunması başlı̆̆ının alt maddeleri olan enerji, su ve malzeme konularındaki yaklaşımları karşılaştırmalı olarak değerlendirilmiştir. Bu çalışmanın gerçekleştirilmesindeki amaç, Türkiye'ye uygun bir sistem 
belirlemek ya da karşılaştırılan sistemler içerisinden birini seçmek değildir. Çalışmadaki asıl amaç, ele alınan sistemlerin enerji, su ve malzeme kriterleri bakımından birbiri ile kıyaslanmasıdır.

Yapılan değerlendirmeler sonucunda, bu üç sistem içerisinde değerlendirilen maddelerin ayrışan ve örtüşen noktaları tespit edilmiştir. Elde edilen sonuçlar değerlendirildiğinde, ele alınan sistemlerinin her birinin söz konusu maddeler üzerinden öne çıkan ve geride kalan yanlarının mevcut olduğu görülmektedir. Gerekli literatür taraması ve bunların 1şı̆̆ında yapılan analizler sonucunda temel kaynaklar olan enerji, su ve malzemenin toplam ağırlığının diğer tüm başlıklara oranla en fazla olduğu sertifikalandırma sisteminin LEED olduğu, bunu sırasıyla ÇEDBİK ve devaminda da BREEAM'in takip ettiği görülmüştür.

Kısaca; LEED’i enerji konusunda öne çıan sistem olarak ele almak mümkündür. Ancak, BREEAM'in karbon konusunda yaklaşımının daha ileride olduğunu da vurgulamak gerekmektedir. BEST'in ise, yenilenebilir enerji kriteri önem taşımaktadır. Su konusunda BREEAM daha geride kalan bir sistemdir. BEST ise, yer altı suları ve atık sular gibi konulara da yer vermesi önem taşımaktadır. Malzeme konusunda dayanıklılık ve çevre dostu olmak temel kriterlerdir. BEST bu konuda geri dönüşüm üzerinden yaklaşımlar geliştirmiştir.

Yapılan değerlendirmeler dikkate alındığında; her bir sistemin kendi coğrafyası ve sosyoekonomik özellikleri doğrultusunda tasarlandığı görülmektedir. Genel bir bakışla; incelenen her bir sistemin çıkış noktasının ve varmak istedikleri yerin aynı olduğu, fakat bunu kendi sistemlerinde farklı düzenlemeler ve kıyaslama ölçütlerindeki farklılıklarla yaptıkları görülmektedir. Dolayısıyla, incelenen sistemler birbirlerine paralel yöntemler ve kriterlerle ilerlemektedir. Bu çalışma ise, bu paralellik içerisinde ortaya çıkan farklılıklar ve benzerlikleri ortaya koyabilmeyi amaçlamıştır.

Yapılan bu çalışmadan hareketle, ilerleyen dönemlerde hem Türkiye'de hem de dünya genelinde yapıların üretim süreçlerinde kullanılan enerjinin ve üretilen atıklarının kontrolüne verilen önemin giderek artacağı düşünülmektedir. Yapım sürecinde karbon salımına yol açan malzemelerin kullanımı, kullanılan ahşapların kökeni gibi konular şu anda da sistemlerin kriterleri arasında bulunmaktadır. Ancak, ilerleyen süreçlerden ağırlıklarının artacağı ve yeni kriterler eklenerek zenginleşebileceği düşünülmektedir. Bu durumun devamı olarak, malzeme başlığı altında geri dönüşüme daha fazla yer verilebileceği de ön görülmektedir.

Diğer taraftan, 2020 y1lı itibari ile küresel çapta yaşan Covid-19 salgının hijyen algısında belirli değişimler yarattığı görülmektedir. Bu durumun özellikle su ve enerji kullanımı bakımından belirli farklılaşmalar yaratacağı düşünülmektedir. Hijyen sebebi ile, kapalı alanlarda klimaların kullanımından kaçınılması ve dolayısıyla da doğal havalandırmalara yönelinmesi, bu farklılaşma için önemli bir örnektir. Bu durumun yanı sıra, dönemin getirdiği sosyal mesafe anlayışının bir sonucu olarak; bağımsız konutlara talep artmakta, konutta yaşam beklentileri değişmektedir. Tüm bu durumların özellikle yeşil binalar ölçeğinde, nasıl bir farklılaşma yaratacağı ise yeni bir tartışma konusudur. 


\section{REFERANSLAR (REFERENCES)}

Aydın, D., Okuyucu, Ş.E. (2009) Yeniden Kullanıma Adaptasyon ve Sosyokültürel Sürdürülebilirlike Bağlamında Afyonkarahisar Millet Hamammın Değerlendirilmesi. MEGARON 2009; 4(1):35-44. İstanbul.

BRE (2016) Breeam International New Construction Guide 2016.

BREEAM | Building Research Establishment Environmental Assessment Method, Web Sitesi: https://www.breeam.com/ erişim tarihi: 12.12.2019

ÇEDBİK (2019) B.E.S.T. - Konut Sertifika Kalavuzu, Ağustos 2019.

ÇEDBİK | Çevre Dostu Yeşil Binalar Derneği, Web Sitesi: http://www.cedbik.org/ erişim tarihi: 12.12.2019

Çelebi G., Gültekin A. B., Ulukavak Harputlugil G., Bedir M., Tereci A., (2008), Yap1-Çevre İlişkileri. TMMOB Mimarlar Odası, Sürekli Mesleki Gelişim Merkezi Yayınları-10, İstanbul.

LEED | U.S. Green Building Council, Web Sitesi: http://www.usgbc.org/leed erişim tarihi: 12.12.2019

Geçer, E., Şentürk, İ., ve Büyükgüngör, H., 2018. Yeşil Bina Tasarımında Su ve Enerji Yönetimi Üzerine Uygulama Örneği. Gümüşhane Üniversitesi Fen Bilimleri Enstitüsü Dergisi. 9 (2), (2019) s.332-343.

Kohler, B. (1999) Defining and achieving sustainable development. International Journal of Sustainable Development \& World Ecology, 6:2, 114-121.

USGBC (2019) LEED v4.1 Residential Single Family Homes, April 2019.

USGBC | U.S. Green Building Council, Web Sitesi: http://www.usgbc.org/ erişim tarihi: 12.12.2019

Sev, A., (2009) Sürdürülebilir Mimarlk.. Yem Yayın, İstanbul, 224s.

Şen, Hüseyin., Kaya, Ayşe., Alpaslan, Barış. (2018) Sürdürülebilirlik Üzerine Tarihsel ve Güncel Bir Perspektif. Ekonomik Yaklassm. 29(107): 1-47.

Tufan, Z. T., Özel, C. (2018) Sürdürülebilirlik Kavramı Ve Yap1 Malzemeleri İçin Sürdürülebilirlik Kriterleri. Uluslararası Sürdürülebilir Mühendislik ve Teknoloji Dergisi. 1(2), 9-13. 


\section{YAZARLARIN BIYYOGRAFİSİ (BIOGRAPHY OF AUTHORS)}

\section{Dostcan Deligöz}

1995 yllında Ankara'da doğdu. İlköğretim ve lise öğrenimini Ankara’da tamamladı. 2013 yllında Çankaya Üniversitesi Mimarlık Fakültesi Mimarlık bölümüne kayıt yaptırarak 2019 y1lında mezun oldu. Aynı yıl başladığı Çankaya Üniversitesi Mimarlık Anabilimdalında yüksek lisans eğitimine ve Hacettepe Üniversitesi İç Mimarlık ve Çevre Tasarımı Bölümünde lisans eğitimine devam etmektedir.

\section{Sueda Kabak}

1997 yllında Ankara'da doğdu. İlköğretimini Ankara'da tamamlamasının ardından lise öğreniminin ilk senelerini KKTC'de, sonrasında Ankara Milli Piyango Anadolu Lisesi'nde tamamlayarak mezun oldu. 2015 yllında Çankaya Üniversitesi Mimarlık Fakültesi Mimarlık bölümüne başladı. 2018 senesinde Erasmus programı ile İtalya'da Alma Mater Studiorum Universita di Bologna'da da eğitim görmesinin ardından Çankaya Üniversitesi’nden 2019 senesinde mezun oldu. Aynı yıl başladığı Çankaya Üniversitesi Mimarlık Anabilimdalındaki yüksek lisans eğitimini sürdürmekle beraber, burada 2020 yllında başladığı yüksek lisans bursiyerliği kapsamında da görev almaktadır.

\section{Arda İlayda Aktan}

Arda İlayda Aktan, 1990 yllında Ankara'da doğmuştur. 2012 y1lında Eskişehir Osmangazi Üniversitesi Mühendislik Mimarlık Fakültesi Mimarlık Bölümü’nde lisans eğitimini tamamlamıştır. 2017 Yıllnda Anadolu Üniversitesi Açık Öğretim Fakültesi Sosyoloji Bölümünden mezun olmuştur. 2019 Yılında Eskişehir Osmangazi Üniversitesi Fen Bilimleri Fakültesi Mimarlık Ana Bilim Dalı Bina Bilgisi Bilim Dalı'nda "Yarışma Yoluyla Elde Edilen Halkevlerinin Kamusal Niteliğinin Mekânsal Olarak İncelenmesi” isimli tez çalışması ile yüksek lisans eğitimini tamamlamıştır. Çankaya Üniversitesi Fen Bilimleri Fakültesi Mimarlık Bölümü’nde Doktora eğitimini sürdürmektedir. 